\title{
Multimodal Nodes: Multimodal Nodes as a Potential for Multilevel Inter- connectivity and Sustainable Development
}

\author{
Sanja Gašparović, Lea Petrović Krajnik* and Tamara Hladki
}

\begin{abstract}
Department of Urban Planning, Spatial Planning and Landscape Architecture, Faculty of Architecture, University of Zagreb, Kačićeva 26, 10000 Zagreb, Croatia
\end{abstract}

\begin{abstract}
The research is based on studying trends that can be read as models of behavior of a contemporary city. The overall area of a city is characterized by a complex dynamics of physical and non-physical space, manifested through networks on different levels. For the purpose of this research, the places of overlapping and/or connecting of two prevailing urban dynamics - dynamics of structurally functional changes (transformation of Brownfield sites) and dynamics of mobility (railway infrastructure), are chosen, which are followed by all other aspects of identified trends (dynamics of space using, dynamics of social interaction, dynamics of environmental networks and flows, dynamics of virtual mobility - information and dynamics of financial investments). The aim of this study is to highlight trends of urban space dynamics and possible benefits of their superposition, as well as to identify possible areas where multiple space benefits can be achieved while summing the effects of specific space dynamics changes. Using comparative analysis, two specific points of convergence - Gare do Oriente and Parque das Nações in Lisbon and a planned Multimodal node Sesvete in Zagreb are examined in order to determine the possible models of dynamic city development. The results show that, with comprehensive and systematic multi-use planning, such locations can gradually become generators of development of the area in which they are located, and have the potential of generating the development of the surrounding areas while achieving multidimensional interconnectivity of urban space.
\end{abstract}

Keywords: Brownfields, Dynamics, Lisbon, Multimodal Node, Mobility, Multilevel Interconnectivity, Zagreb - Sesvete, Transformation.

\section{INTRODUCTION - DYNAMICS AS ONE OF THE BASIC FEATURES OF CONTEMPORANEITY}

The research is based on studying trends that can be read as models of behavior of a contemporary city. The dynamics of space and the dynamics of life became some of the most prominent features of contemporaneity. The overall area of the city is characterized by a complex dynamics of physical and non-physical space, manifested through networks. According to Manuel Castells (2002), today's society is a "networked society" and the most important term for understanding the information age is "network" [1]. Therefore, the complex dynamics of physical and non-physical space is considered on the following levels:

Mobility dynamics can be identified through demands for an increasing transport efficiency and speed. The space is ever more densely cross-linked with various forms of transport infrastructure - physical routes which together form a system and intersect at different spatial levels. Because of their dimensions, traffic-technical requirements and longitudinality, infrastructure corridors often represent structural and functional barriers in space. Modern times ever more

*Address correspondence to this author at the Department of Urban Planning, Spatial Planning and Landscape Architecture, Faculty of Architecture, University of Zagreb, Kačićeva 26, 10000 Zagreb, Croatia;

Tel: +385 14639 197; E-mail: lea.petrovic@arhitekt.hr often set requirements for designing their multifunctionality [2] and identity [3] and they are recognized by numerous studies [4] as the most important generative public spaces. This omnipresent urban environment, often considered and evaluated solely through technical criteria, now is considered also through new functions - social, environmental and aesthetic [5].

Dynamics of structural and functional changes in the city are visible, among other things, through numerous examples of Brownfield transformations. For the purpose of sustainable planning, cities are built and developed from the inside, by infilling voids or by transforming specific areas within the already established city boundaries. As the results of that specific development, Brownfield transformations are one of the main features of many contemporary cities ${ }^{1}$. They generate changes in urban areas at different levels (regional, city and local), instigating a number of positive development processes with multiple impacts on the wider spatial context.

Dynamics of space using is manifested through setting the requirements for multifunctional intensive land use. To optimize the built environment and contribute to sustainable development it is necessary to combine land uses in time and space. The social ecology of places is thus improved while minimizing their ecological footprint [6].

\footnotetext{
${ }^{1}$ Sometimes it is about entire regions, such as the project for the Emscher Park or the development strategies for cities like London, Seville, Hanover, Lisbon and others.
} 
The establishment of dynamics of social interaction is crucial for successful planning of urban life. It is necessary here to point out open public spaces as physical networks that significantly stimulate the dynamics of movement [7] and enable the manifestation of social connectivity in space, thus representing one of the very important elements of the city image.

Respecting the dynamics of environmental networks and flows, as one of the segments of sustainable development, is becoming the standard of a contemporary city. Therefore, aspects such as the use of alternative energy sources and environmental protection are some of the primary starting points of modern sustainable planning.

The dynamics of virtual mobility - information and the dynamics of financial investments, although nonphysical forms, are among the most prominent features of contemporaneity. They significantly determine the dynamics of life of individuals and the society, change habits and customs, influence social and economic aspects of life and indirectly influence all other aspects of the physical manifestation of the city and the region. The mobilization of substantial dynamics of financial resources around a single goal - a particular city or state strategy - enables a large-scale intervention in a much shorter period than usual, as well as the implementation of projects that otherwise would not be realized [8].

The aim of this study is to highlight trends of urban space dynamics and possible benefits of their superposition, and to identify possible areas where multiple space benefits can be achieved while summing the effects of specific space dynamics changes.

For the purpose of this research, the places of overlapping and/or connecting of two prevailing urban dynamics dynamics of structurally functional changes (transformation of Brownfield sites) and dynamics of mobility (railway infrastructure) - are chosen, followed by all other aspects of identified trends.

Such specific points of convergence are examined through different examples to determine the possible models of dynamic city development. The analyzed points represent multimodal nodes - places of encounter and connection of physical and non-physical networks, dynamic flows and changes. The research starts from the hypothesis that a multimodal node can become a place of creating new identity and a generator of development of the area at the local, regional and national level.

\section{FEATURES OF ZAGREB URBAN DYNAMICS}

In recent decades, a number of European cities have used their urban strategies for successful acceleration of their development ${ }^{2}$. For the time being, such strategies have not been realized in Zagreb in the new millennium, despite evident dynamic urban development processes until the end of the twentieth century. In the 1990 s, Croatia was struck by war, followed by a turbulent period of transition and finally of economic stagnation and decline, all of which led to the ab-

\footnotetext{
${ }^{2}$ Madrid RiO, London Olympic Games 2012, Hamburg - Haffen city, Copenhagen -
} Ørestad, Lisabon EXPO'98 and others sence of preconditions for realizing the desired urban dynamics.

One of the positive examples of a large city and government project implemented in the 1980s in the city of Zagreb, which prompted various forms of urban dynamics, was the Summer Universiade in 1987. The Universiade, although primarily a sporting event, had multiple significances for the city, the region and the country. Despite the crisis and inflation, it brought Zagreb and its wider surroundings numerous realizations. In the preparatory period, there were numerous individual and group interventions in the urban structure (construction of new and modernization of existing sports facilities, infrastructural interventions in the railway and road transport system, construction of new accommodation capacities and other supporting facilities, renovation of public spaces and refurbishing of facades in the Downtown). In addition to the newly built or modernized infrastructural network and suprastructure, a very significant benefit for the city, the region and the country was the promotion on the national and international levels and the establishment of recognition and new identity [9].

This study primarily aims at pointing out the potential places of urban dynamics and stimulating the finding of the optimal model of their implementation, based on the comparative analysis of European examples.

One of the most significant development features of the city of Zagreb was the construction of the railway in the second half of the $19^{\text {th }}$ century. Besides the undeniable economic impulse, the city also got a strong infrastructural barrier extending in the east - west direction. It conditions the longitudinal expansion of the city, and in many urban areas becomes a place of separation of certain developmental stages of the city and separate allocations. At the time of its construction, the industrial zone was usually located south to it whereas the "city" was on its northern side.

The beginning of the $21^{\text {st }}$ century was marked by a number of proposals for developing and improving the railway. City authorities in collaboration with experts in the field of railway transport planned to expand the railway system and better incorporate it in the public transport network. That way the railway infrastructure would be transformed from a barrier to one of the main city connectors. Consequently, a number of urban areas located along the railway corridor would undergo transformation - consolidation in the case of unfinished urban neighborhoods and conversion in the case of abandoned industrial areas (Brownfield sites). Recent research into the development of the City of Zagreb largely concerned suggestions of possible strategies of urban development along the railway infrastructure. Possible locations for urban railway stations as development potentials of new urban centers are studied, as well as possibilities for the conversion and transformation of industrial facilities that have until recently been in a function of the railway in the city center and new scenarios for elevating and lowering the vertical alignment of the entire urban railway corridor.

The trend of sustainable city development is evident from the consideration of possibilities for urban transformation of abandoned military and industrial areas which represent a great potential in the City of Zagreb. Brownfield areas and 


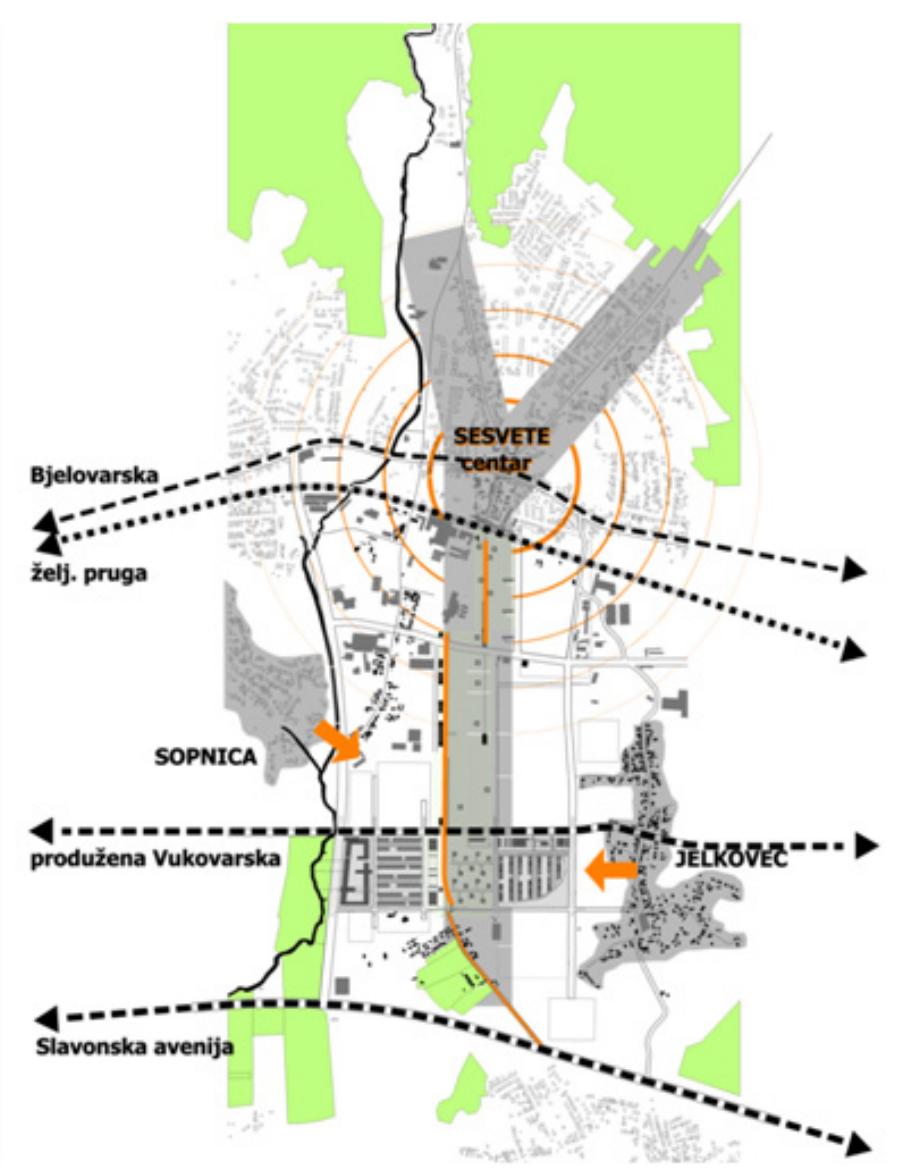

Fig. (1). Spatial context of Sesvete, Zagreb. Source: Gašparović S 2003.

individual complexes or buildings protected by spatial planning documents in strategically important locations in the city are awaiting proposals for new programs and integration in the complex dynamics of the city.

The Zagreb Association of Architects in cooperation with the City of Zagreb carried out urban planning and architectural competitions for specific abandoned industrial complexes to be included in the offer of public and social spaces of the city. Furthermore, several successful conversions of buildings belonging to industrial heritage have already found their place on the new cultural map of the city. Special attention is given to plans for the transformation of Brownfield sites into residential developments. The subsidized housing program [10] initiated by the government at the beginning of the $21^{\text {st }}$ century contains many architectural realizations of residential buildings of exceptionally high quality. Two fully realized residential developments - Spansko - Oranice in the western part of the city on the grounds of former military barracks and Sopnica Jelkovec (today known as Novi Jelkovec) in Sesvete in the eastern part of the city on the grounds of a former pig farm ${ }^{3}$ are considered to be special contributions (Fig. 1) [11].

The aforementioned potentials for the urban development of Zagreb lead to the conclusion that some of the most important transformations in the future can be expected in

\footnotetext{
${ }^{3}$ During the period of the 1990s most of the housing construction in Zagreb was carried out through single constructions of residential buildings. Therefore, the implementation of comprehensive residential development stimulated by the subsidized housing program is considered as a special contribution to the strategic planning of the city.
}

places where Brownfield sites and railway corridors meet. Unlike the central city area, which has been studied in great detail for a number of years (studies, competitions, workshops, etc.), periphery areas of the city are less studied, although recognized in spatial planning documents. Therefore, such peripheral areas were chosen as case study locations for this research.

\section{CASE STUDIES - PARQUE DAS NAÇÕES (LISBON) AND SESVETE (ZAGREB)}

For the purpose of this research, two examples of areas related to railway and transformation of former industrial areas (Brownfield) were chosen. The selected cities are comparable in terms of the number of inhabitants, the surface area of Brownfield areas transformed and the location of the Brownfield in the city. In addition, the incentive for their implementation came from urban/state projects. In the case of Lisbon it was the organization of EXPO '98 under the auspices of the Bureau International des Expositions and in the case of Zagreb the government-sponsored subsidized housing program in Sesvete. Parque das Nações in Lisbon with a multimodal station Gare do Oriente represents a generator of development of the Lisbon's eastern coastal zone and its wider metropolitan region. The residential development Sopnica Jelkovec together with the planned multimodal node in Sesvete were considered as possible generators of development of the City of Zagreb. All elements of complex dynamics of physical and non-physical space (dynamics of 


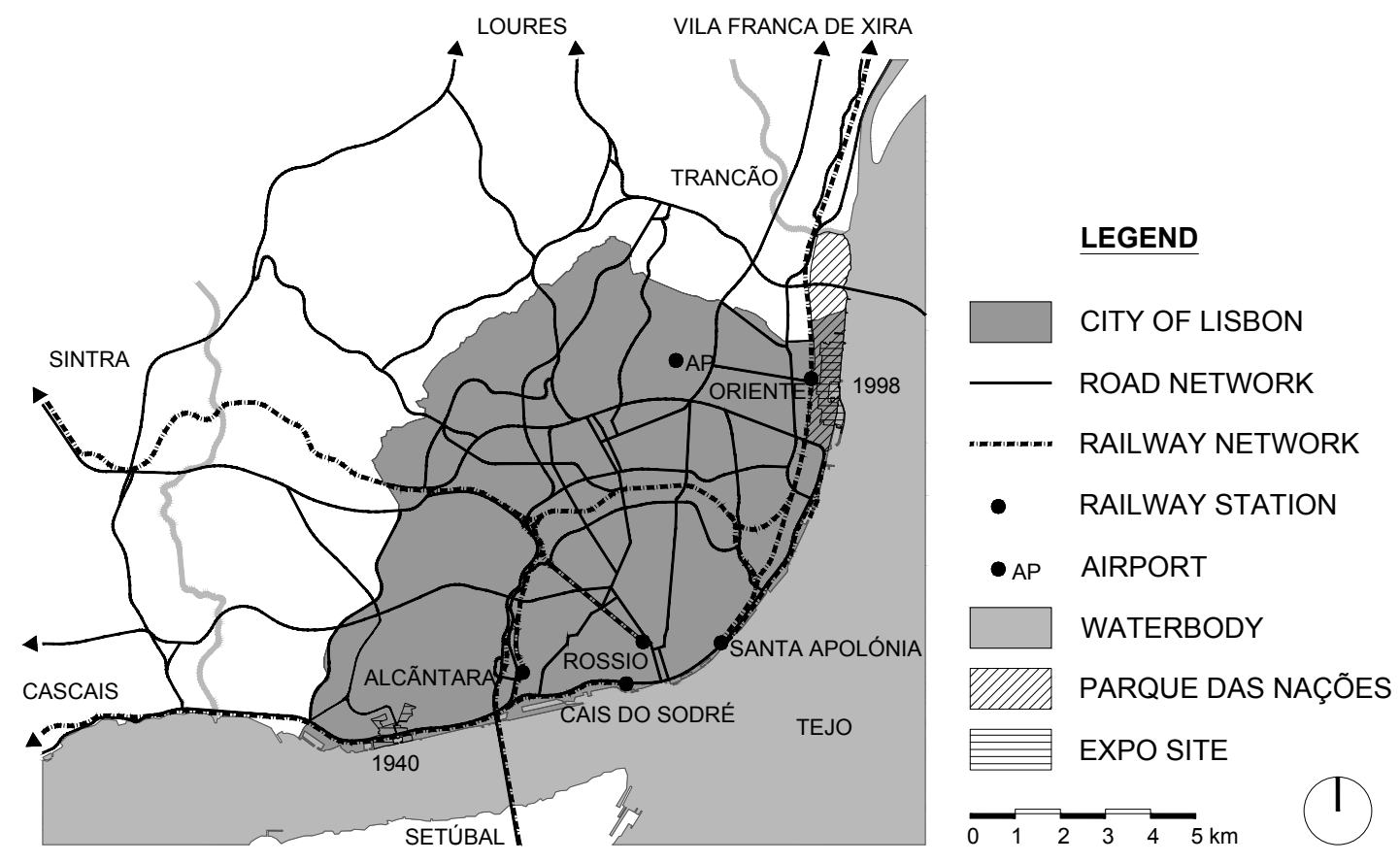

Fig. (2). Location of the "Intervention Zone" - Parque das Nações. Source: Petrović Krajnik L 2014.

mobility, dynamics of structurally functional changes, dynamics of space using, dynamics of social interaction, dynamics of environmental networks and flows, dynamics of virtual mobility) were taken into consideration as elements of comparative analysis.

\subsection{Case Study - Parque das Nações (Lisbon)}

Development of the Lisbon transport system took place simultaneously with the development of the city's urban structure and its wider region, and was significantly conditioned by the geomorphological features of the area and the location of Lisbon on the Atlantic coast, along the estuary of the River Tagus.

The emergence of railways in the mid- $19^{\text {th }}$ century and insufficient road network intensified the construction of the railway network in Lisbon in the second half of the $19^{\text {th }}$ century. The first railway route from north to south ran through the eastern coastal zone of Lisbon to the Cais dos Soldados, where the terminus Santa Apolónia was built in 1866. To connect the port of Lisbon with the northern and eastern railway routes, a circular line was built around the city during the 1880s. It was followed by the construction of the western terminus Alcântara with a branch towards Sintra. The terminus Rossio, built in the late $19^{\text {th }}$ century on former medieval fortifications, became the main railway station, linked to the circular railway route by a tunnel. In the same period a new route was built along the city's western coastal area with the terminus Cais do Sodré located next to the Lisbon port [12] (Fig. 2).
In the preparatory period leading to the EXPO '98, besides significant problems in road traffic (congestion due to an increased number of vehicles) Lisbon also had considerable problems in railroad traffic (insufficient accessibility to the southern bank of the River Tagus, inarticulateness between suburban and regional/national functions of the railway network) which had to be solved [13].

In 1990, with the decision to organize the EXPO '98 in Lisbon under the authority of Bureau International des Expositions, the period of intense changes in the transport sector of the city and higher territorial units began. A study for the selection of the EXPO '98 location was made, with the main criterion being the location's accessibility by transportation networks on the national, regional and city level. The study identified necessary interventions in all segments of the transport system. In the eastern part of the city, on the site of the former Oriente train station, $3 \mathrm{~km}$ away from Aeroporto do Portela airport, a new multimodal station Gare do Oriente was located, programmed to serve as a multitransport interchange and a western entrance to the EXPO '98 site.

The area selected for the EXPO '98 was located in the eastern coastal area of Lisbon and formed a central part of the wider Intervention Zone ( 350 ha in surface, today known as Parque das Nações). The Intervention Zone, bordered by the eastern railway route to the west, the River Tagus to the east, the River Trancão to the north and Avenida Marechal Gomes da Costa to the south, was planned for a comprehen- 


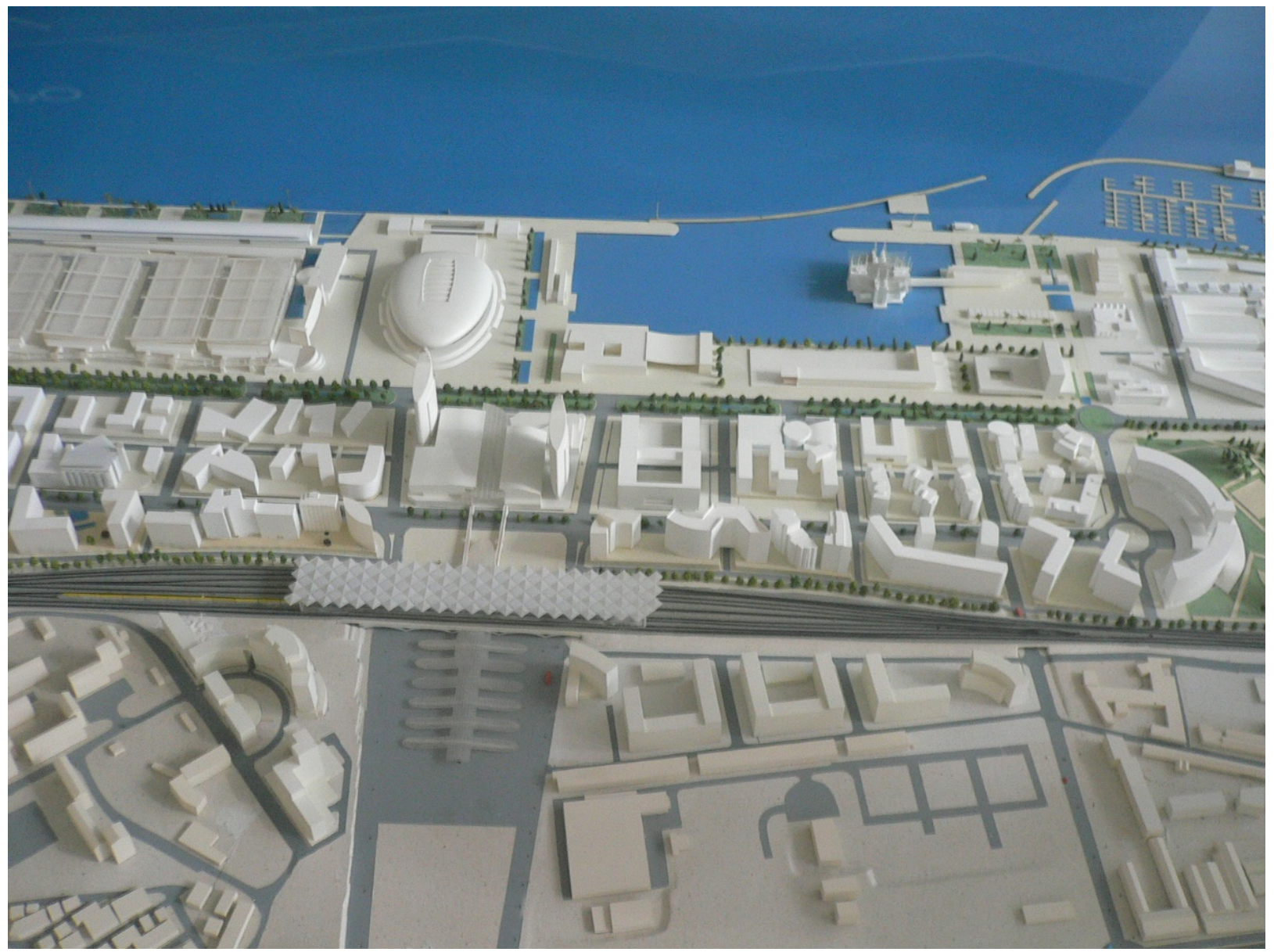

Fig. (3). Model of Parque das Nações - central area. Source: Petrović L 2009.

sive transformation of the industrial and port area into a new focus of development of the city and the region.

Already the first proposal of the Master Plan of Lisbon, Plano Geral de Urbanização e Expansão de Lisboa (19381948), defined the eastern coastal area as the main industrial zone of the city. By the same plan, the former industrial zone located in the western and central coastal areas of the city was designated for gradual transformation into the noble city area. Gradual transformation of that area was stimulated by the Exposição do Mundo Português held in 1940 on the south-western part of Lisbon in the parish of Belém [14].

Since the 1940s the eastern coastal zone has accommodated large industrial plants and various port facilities whose structure and function gave the area a distinctive character. The importance of the central area called Doca dos Olivais, located close to the present-day multi-modal Oriente station, is indicated by its function as a freight terminal and the use of the maritime port Cabo Ruivo for hydroplanes on the USA - Europe route between the 1940s and the 1950s.

Having been predominantly used for industrial purposes and for the purposes of the port for almost half a century, coupled with the lack of legislation for environmental planning and indispensable interventions, the eastern coastal area of Lisbon was degraded and contaminated, while the River Tagus and its tributary Trancão were contaminated by waste water [15].
The selection of the area between Doca dos Olivais and Beirolas, which had hitherto been a structural and functional barrier for urban development and opening to the River Tagus, for the site of the EXPO '98 in 1991 instigated significant transformation of the overall eastern coastal area of Lisbon and regeneration of the riverfront, including comprehensive cleaning of the whole area and its environmental requalification.

In the preparatory period of EXPO '98, on the basis of previously made studies, the urban plan of the whole area of the today's Parque das Nações was elaborated together with seven legally binding land use plans (three for predominantly residential purposes, one for predominantly commercial purposes, one for a mainly public purpose and one for Parque Tejo). The overall strategic project EXPO '98, consideration of space and long-term needs, as well as the planning and designing themselves were all based on the principles of sustainability (Fig. 3) ${ }^{4}$.

Organization of EXPO '98 was one of the stages in the process of transforming the entire Parque das Nações area. The eastern coastal zone is nowadays undergoing further

\footnotetext{
${ }^{4}$ Long-term planning, environmental requalification, purification and rehabilitation of the entire area, recycling of materials found in the subject area, permanent monitoring, multifunctional use of space, density, minimal consumption of energy and waste treatment and management - Galeria Técnica - space where optical cables, heating and cooling networks, central collection of solid waste, etc. are placed, social diversity, identity, aesthetics, flexibility, maintenance services, diversity of work, etc.
} 


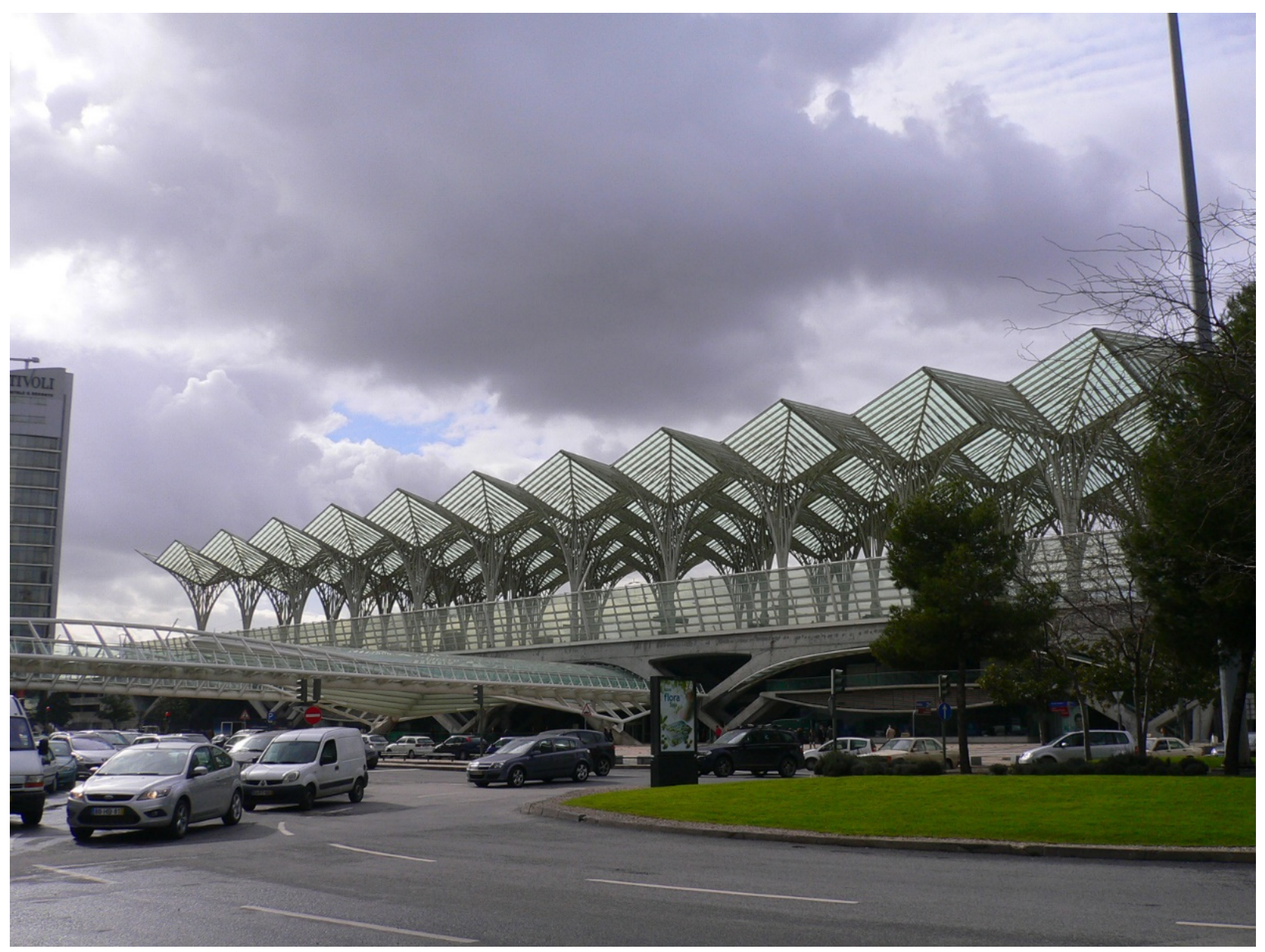

Fig. (4). Gare do Oriente in Lisbon. Source: Petrović L 2009.

development, as confirmed by the development of new plans - Plano de Urbanização da Zona Ribeirinha Oriental (2008) which determines the general organization of the wider area.

The multimodal station Gare do Oriente, designed by architect Santiago Calatrava, is the main transport hub of Lisbon. The multimodal station complex comprises a Lisbon metro station (a new metro line was introduced on the occasion of organizing EXPO '98), a high-speed, commuter and regional train hub, a local, national and international bus station and car park. The station also features additional facilities for leisure and entertainment, a shopping center and a police station. It is a place of multilevel interconnection of traffic, a multiuse and a social interaction (Fig. 4).

The multimodal station Gare do Oriente, a transport hub, together with the shopping center Vasco da Gama (formerly Western Gateway at EXPO '98) constitute the main focus of the newly built area Parque das Nações and contribute to the creation of a new pole of development of the Lisbon metropolitan area. They represent the main point of convergence of complex physical and non-physical spatial networks on the Lisbon eastern coastal zone. Their design and scale created new spatial identity and recognisability, while their multifunctionality contributes to improving the quality of life and sustainable development of the whole area.

\subsection{The Case Study of Sesvete (Zagreb)}

The selection of the Sesvete case study was motivated by research and a project conducted as part of the final semes$\operatorname{ter}^{5}$ - Master Theses Studio at the Faculty of Architecture of the University of Zagreb.

Sesvete is the largest city district of Zagreb, located on its northeastern edge, characterized by a number of transformation processes that have already begun or new potential transformations that will take place in the near future. The area has, therefore, become an intriguing testing ground for different models of urban strategies for future development while preserving the inherited values of the space.

The focus of the graduate research is on the contact area between the historical city center and the abandoned industrial zone nowadays separated by the railway infrastructure. The project starts from the premise that the newly planned multi-modal node in that location can and should be used as the generator of future development and a way of establishing physical networks presently missing with a view of establishing the new urban dynamics. During the research phase, the Lisbon example was purposed to be used as one of

\footnotetext{
${ }^{5}$ For the purpose of the Master Thesis of the student Tamara Hladki made under the supervision of Sanja Gašparović as the mentor and Lea Petrović Krajnik as the comentor.
} 


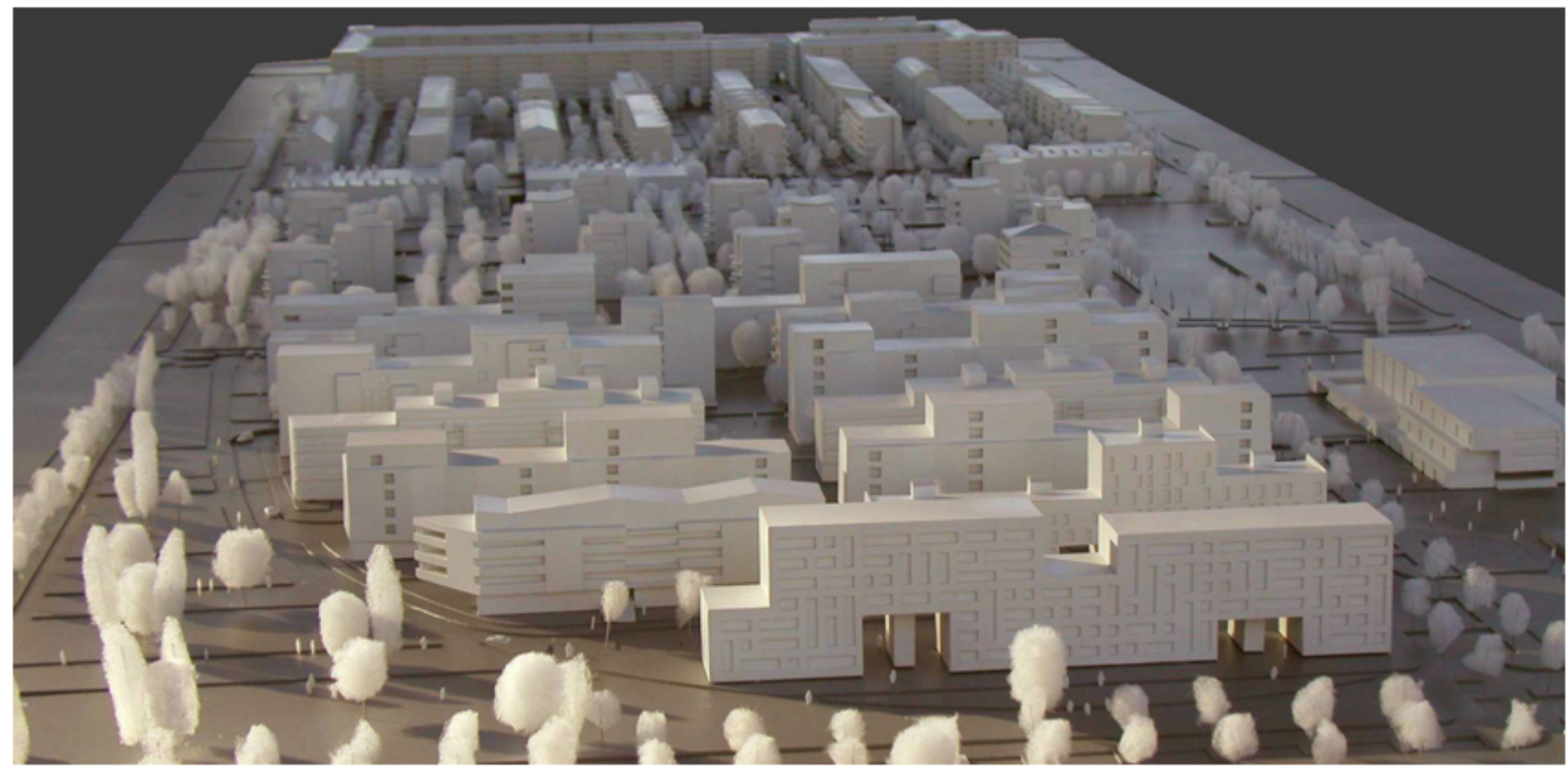

Fig. (5). Model of residential development Sopnica Jelkovec in Sesvete. Source: Gašparović S 2003.

the more referential comparative models due to a series of coincidences which can be identified in both spaces.

Historically, the settlement of Sesvete was first mentioned as a turnpike in the early $14^{\text {th }}$ century, but the significant development began in the $19^{\text {th }}$ century with the construction of the railway on what was the southern edge of the settlement at the time. The new infrastructure had a favorable impact on economic development and had also impacted the settlement's spatial and functional organization. The railway was both a spatial barrier and an element dividing the settlement into northern, predominantly residential area and the southern area largely intended for agriculture and industry.

In the mid- $20^{\text {th }}$ century, the first dynamic transformation began with rapid development of the predominantly meat processing industry, the largest and the most modern in the former Yugoslavia at the time. As early as the 1970s, industrial production gradually started declining and the last plants closed down at the turn of the $21^{\text {st }}$ century. The area of Sesvete south of the railway has since remained undefined / unused (Brownfield area of around $300 \mathrm{ha}$ ) and represents the largest spatial potential for future expansion. Fragments of it have been converted into individual trade or business facilities, but without a clear strategy for the development of the overall area and its role in the future development of Sesvete and the City of Zagreb.

The largest conceptual shift in the former dual functional division on the area north and south of the railway began with the construction of the residential development Sopnica Jelkovec on the grounds of a former pig farm, located about $1.5 \mathrm{~km}$ from the historic center of Sesvete south to the railway line. In 2003, this single plot of almost 34 hectares and with resolved ownership issues was used for the realization of one of rare comprehensive residential developments for as many as 2700 inhabitants within the government program for subsidized housing [11] (Fig. 5).

The residential development was realized following a public urban planning and architectural competition and a legally binding land use plan [16]. The most eminent Croatian architects were chosen to design 54 residential buildings and a number of public, social and related facilities. Such a concept largely solved the deficit of social housing in Zagreb and significantly contributed to the state social housing policy. With its scale, strong urban concept and high social standards, this residential development became a new landmark in the area and established a new urbanity. With the location of such a large residential complex in the area previously predominantly used for industrial purposes undoubtfully marked the beginning of structural and functional transformation of the Brownfield. Sopnica Jelkovec has thus "overcome" the former barrier and set the foundation for a new identity structuring of the part of the city south of the railway.

The development and transformation of the surrounding area and the necessary physical connection with the presentday center and the existing urban facilities of Sesvete had not been carried out simultaneously with the building of the new residential development, making this residential development still an island in an undefined and undeveloped area whose new identity is yet to be formed. The research carried out as part of the master's program revealed that Sesvete lost one of its most important identity features in the $20^{\text {th }}$ century with the abandonment of industry, while the railway remained a spatial barrier hard to overcome [17].

The historical center of Sesvete is congested by parked vehicles and divided by a heavily-used main road, lacking open public spaces and buildings intended for social purposes. On the other hand, although leaning on the densely 


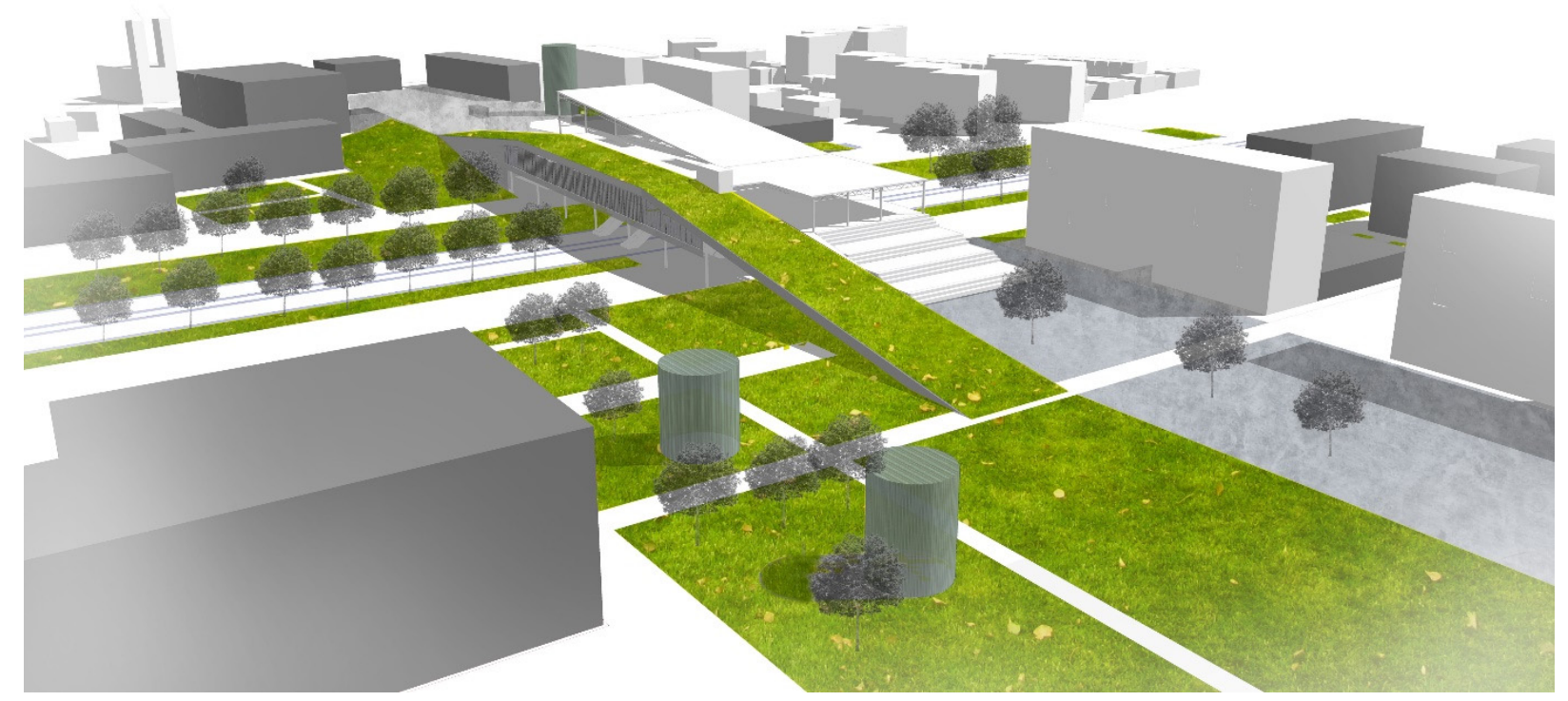

Fig. (6). Proposal for multimodal node in sesvete. Source: Hladki T 2014.

built urban structure, the district of Sesvete features valuable landscape that descends from the slopes of the Medvednica Mountain and penetrates into the very structure of Sesvete. Traces of the area's historical identity are largely preserved, but insufficiently exploited and not integrated in the image of the urban center.

The goals of the Master Thesis project of the multimodal node in Sesvete were to establish the necessary connections (spatial and facilities), reduce identified deficiencies, preserve and enhance the heritage and establish new legibility and unity of the planned and already designed space. The project envisaged the largest structural and functional change in the area north and south of the railway in the immediate contact with the infrastructural node. A new solid urban structure of strong facades, on the site of the former meat industry Sljeme aims to consolidate the area of Brownfield transformation and thus become the new area of mixed use and new businesses at the junction north and south of the railway line.

The demanding multimodal traffic node envisaged and integrated a multilevel traffic solution. Its highest platform arches over the railroad and includes a pedestrian path connected with a new linear pedestrian route in the north - south direction, linking the parts of the area formerly disconnected. The new structural-functional unit consists of: the historic center with the newly established square, a new pedestrianonly platform of the station functioning also as a market - a multipurpose urban public space, and a strip of newly landscaped areas extending all the way to Sopnica Jelkovec on the trace of the former Roman path protected in the spatial planning document. The partially covered area of the new market / multimodal node is conceived as a linear park which establishes connection and continuity with the landscape of Sesvete. It is also designed as a surface for collecting rainwater and solar energy with the aim of achieving a sustainable building concept (Fig. 6).
The multimodal node thus designed represents a point of convergence of the complex dynamics of physical and nonphysical space - a multipurpose space enabling the greatest possible flexible use. It is a place of multilevel transport interconnectivity (train, bus station, taxi, bicycles, pedestrians), multi-use (market, restaurants and bars, a multi-purpose square) as a space of socialization, that connects currently unconnected parts of the city. Due to its scale and modern design it could become a new feature of Sesvete.

\section{CONCLUSION}

Multidimensional spatial dynamics, as basic features of contemporaneity, can be seen in both of the selected examples. Both of them are about the transformation of Brownfield areas comparable in size, location within the city and their relation to large railway infrastructure. They differ in the relevance and character of the city/state projects which instigated their implementation and the time difference between their implementation (approximately 10 years), including different economic situations across Europe. The above mentioned resulted in different successes of their implementation and different levels of completion.

The success of the Lisbon example shows that only comprehensive (studies, urban plans, legally binding land use plans), continuous and flexible planning with continual monitoring and reacting to the developmental dynamics of space (modifications and amendments of spatial planning documents) leads to successful transformation of a specific area and its integration into the surrounding tissue with an adequate stimulus of any type of city/government projects. To reduce the danger of a fragmentary realization of spatial isolated islands, such as Sesvete are for the time being, it is necessary to simultaneously plan the development of 
the entire area to be transformed, and in particular its infrastructure, with a well-conceived complex spatial-temporal/dynamic concept. This study wanted to point out the potential places of urban dynamics and encourage the finding of an optimal model for their realization.

Organizing the EXPO '98 in Lisbon was undoubtedly the project of the highest rank on the city/state level, requiring substantial investments and realization in a short period, which resulted in positive benefits in the long run not just for the transformed area but for the whole city and the region.

The question arises whether Croatia and Zagreb, under the current economic conditions, have the strength to organize similar large events or whether other models would be more appropriate to stimulate new spatial dynamics. Since Croatia joined the European Union in 2013 and new funding opportunities become available, the transformation and modernization of the railway infrastructure as part of the European railway network is now inevitable. Such investments and interventions will lead to a range of spatial transformations in the immediate environment of the railway corridor, corroborating the claim that these places are potentially the first in line for the future development of the City of Zagreb.

Research has shown that comprehensive and systematic multi-use planning of such locations can establish forces of development of the wider city area and achieve multidimensional interconnectivity of urban space. These places gradually become generators of development of the area in which they are located, and have the potential of generating the development of the surrounding area, in particular through the multipurpose program primarily in the function of the city public space.

The analyzed examples have shown the indicators of the current trends in urban dynamics with multimodal nodes as their focuses and the ways to achieve benefits for the wider area at the local, regional and national level by superimposing them.

Mobility dynamics has been achieved and improved by establishing points of convergence of different physical networks of dynamic movements previously non-consolidated and/or representing a barrier in space. Monofunctional characteristics of infrastructure are reduced and it becomes a multipurpose public urban space.

Dynamics of structural and functional changes are stimulated with the transformation of significant parts of Brownfields, leading to gradual economic, environmental, social and identity transformation of abandoned and for citizens "invisible" parts of the city.

Dynamic of space using is established with a flexible and multifunctional use of space, which thus contributes to the establishment of a new impulse of vibrancy and frequency of use of the area, thus in turn also of the whole city and region.

Dynamics of social interaction is enabled and ensured, with non-physical interconnectivity and its manifestation in space with a high proportion of public open pedestrian areas that such projects win for the city and citizens, and integrate into the wider spatial network.
Dynamics of environmental networks and flows is achieved through the obligation to implement measures for purification and healing of the space used for many years for industrial purposes, and through planning in accordance with the principles of sustainability.

Dynamics of virtual mobility - information and dynamics of financial investments are triggered with the implementation of new infrastructural networks, and city/state projects have enabled the dynamics of substantial financial resources around a single goal which led to the realization of large-scale interventions in a much shorter period than usual and to the realization of projects which would otherwise not been realized.

The research confirmed the hypothesis that a multimodal node, as a place of encounter and interconnection of physical and non-physical networks, dynamic flows and city changes, can become a place of creation of a new identity and a generator of development of the wider area. Depending on their importance, such nodes can become new "small cities" and their superstructures a distinctive element in the new image of the city or region.

\section{CONFLICT OF INTEREST}

The authors confirm that this article content has no conflict of interest.

\section{ACKNOWLEDGEMENTS}

This research is a part of the scientific project Heritage Urbanism - Urban and Spatial Planning Models for Revival and Enhancement of Cultural Heritage (2032) financed by Croatian Science Foundation, which is being carried out at the Faculty of Architecture, University of Zagreb, under the project leadership of Prof. Dr. Sc. Mladen Obad Šćitaroci.

\section{REFERENCES}

[1] Castells M. The rise of the network society: the information age: economy, society and culture, vol. I. US: Blackwell Publishing 2010.

[2] Gašparović S, Highway as the possibility for unveiling the value and the multi-layer character of the landscape. $\mathrm{PhD}$ thesis. Croatia: University of Zagreb 2009.

[3] Augé M, Non-places: an introduction to an anthropolosy of supermodernity. London-NY: Verso 1995.

[4] Calabrese ML, Houben F. Mobility: a room with a view. Rotterdam: Nai Publisher 2003.

[5] Mossop E. Landscapes of Infrastructure. In: Waldheim C, Ed. The Landscape Urbanisam Reader. US: Princeton Architectural Press 2006.

[6] Haccoû HA, Deelstra T, Jain A, Pamer V, Krosnicka K, de Waard R, Eds. MILU, Multifunctional intensive land use - principles, practices, projects, policies. Netherlands: The Habiforum Foundation 2007.

[7] Marić T, Obad-Šćitaroci BB. Walkspace - linear space - motion in the city of split (Walkspace: Linearno povezivanje prostora na primjeru Splita). Prostor 2012; 20(1): 118-31.

[8] Petrović L. Impact of the world exhibition on urban and regional development. PhD thesis. Austria: Technische Universität Graz 2009.

[9] Zekić J. Universiade '87 - Second Illyrian revival (Univerzijada '87. - drugi ilirski preporod). Časopis za suvremenu povijest 2007; 39(2): 299-318. 
[10] Bobovec B, Mlinar I. Social housing construction scheme in croatia (Program društveno poticane stanogradnje u Hrvatskoj). Prostor 2013; 21(1): 140-57.

[11] Mlinar I, Śmit K. Urban-planning parameters in the analysis of housing developments zapruđe and sopnica-jelkovec in zagreb (Urbanistički pokazatelji zagrebačkih stambenih naselja Zapruđe i Sopnica-Jelkovec). Prostor 2008; 16(1): 116-25.

[12] Pinheiro M. Portuguese cities and railways in the $19^{\text {th }}$ and $20^{\text {th }}$ century. In: Roth R, Polino m-N. Eds. The city and the railway in Europe. UK: Ashgate 2003; pp.105-18.

[13] Petrović Krajnik L. EXPO'98 and changes in lisbon's transport system (EXPO'98 i promjene u prometnom sustavu Lisabona). Prostor 2010; 18(1): 178-89.
[14] Krajnik LP. The functional and structural transformation of the eastern coastal zone of lisbon induced by expo'98. In: Proceedings of The $2^{\text {nd }}$ International Conference on Sustainable Architecture and Urban Development - vol. 3; CSAAR. Amman, Jordan 2010; pp. 345-60

[15] Velez JP. Ed. Documentos para a história da EXPO'98 (19891992). Lisboa: Parque das Nações, Parque EXPO’98, SA. 1999.

[16] Gašparović S, Maletić Mirko D, Martinčić N, Mlinar I, Premužić M, Śmit K. Legally binding land use plan for residential development sopnica jelkovec (Detaljni plan uređenja stambenog naselja Sopnica Jelkovec). Faculty of Architecture, Institute for Urban planning. Spatial Planning and Landscape Architecture 2003.

[17] Hladki T. Urban planning and architectural proposal for the centre of sesvete (Urbanističko-arhitektonsko rješenje središta Sesveta). Master Thesis. Croatia: University of Zagreb 2014.

Received: June 10, 2015

Revised: June 15, 2015

Accepted: June 15, 2015

(C) Gašparović et al.; Licensee Bentham Open.

This is an open access articles licensed under the terms of the Creative Commons Attribution-Non-Commercial 4.0 International Public License (CC BY-NC

4.0) (https://creativecommons.org/licenses/by-nc/4.0/legalcode), which permits unrestricted, non-commercial use, distribution and reproduction in any medium, provided that the work is properly cited. 